Article

\title{
Environmental Regulation, Environmental Commitment, Sustainability Exploration/Exploitation Innovation, and Firm Sustainable Development
}

\author{
Xinpeng Xing ${ }^{1}{ }^{\mathbb{D}}$, Tiansen Liu ${ }^{2}$, Jianhua Wang ${ }^{1,3, *}$, Lin Shen ${ }^{1}$ and Yue Zhu ${ }^{4}$ \\ 1 School of Business, Jiangnan University, Wuxi 214122, China; xinpeng@jiangnan.edu.cn (X.X.); \\ kcggyx2017@163.com (L.S.) \\ 2 School of Economics and Management, Harbin Engineering University, Harbin 150001, China; \\ tiansen0328@hotmail.com \\ 3 Food Safety Research Base of Jiangsu Province, Jiangnan University, Wuxi 214122, China \\ 4 School of Management, Harbin Institute of Technology, Harbin 150001, China; zhuyue@hit.edu.cn \\ * Correspondence: jianhua.w@jiangnan.edu.cn
}

Received: 23 August 2019; Accepted: 23 October 2019; Published: 28 October 2019

\begin{abstract}
The links among firms' environmental regulation, innovation process, and sustainable development has been analyzed, but a research gap still remains in terms of environmental commitment and different types of sustainable innovation in firms' sustainability. Through collecting a dataset of 380 valid respondents from Chinese manufacturing firms, this paper incorporates evironmental regulation, environmental commitment, sustainability exploration innovation, sustainability exploitation innovation, environmental performance, and business performance into a multiple mediating effect model. Our key emperical findings are as follows: (1) Environmental regulation not only cannot affect environmental performance and business performance, but also cannot affect the two types of firm performance through sustainability exploration innovation or sustainability exploitation innovation; (2) The relationship between environmental regulation, environmental performance (or business performance) is subsequently mediated by both environmental commitment and sustainability exploitation innovation; (3) Environmental regulation does not affect environmental performance (or business performance) through environmental commitment and sustainability exploration innovation. These results do, however, support the Porter Hypothesis in terms of revealing a new multiple mediating effect path dominated by environmental commitment and sustainability exploitation innovation. Our findings can provide a better understanding of how environmental commitment and sustainability exploitation innovation play a key effect in helping firms relieve the pressure from environmental regulation, and thus improve their environmental management while keeping their competitive edge.
\end{abstract}

Keywords: environmental regulation; environmental commitment; sustainability exploration innovation; sustainability exploitation innovation; Porter Hypothesis; Chinese manufacturing firms

\section{Introduction}

The dominant mode of economic growth at present has led to an enormous consumption of materials and energy that triggers the large-size pollutants emission, which has intensified the conflict between environmental protection and economic development. To alleviate this dilemma, governments worldwide broadly developed environmental regulation (EREG) tools [1,2]. However, EREG is seen as a passive and compulsory mechanism that is likely to increase firms' environmental management costs, thus bringing a negative effect on firm performance [3]. At the same time, flexible regulation tools can optimize market structures, reduce production costs while improving operations efficiency, thus helping firms to keep their competitive edge [4,5]. However, whether these regulation tools can 
improve firms' sustainable development is still controversial, and this is also expected to expand the theoretical explanation of Porter Hypothesis.

A lots of studies investigated the controversy in terms of the effect of EREG on firm performance with a key finding being that EREG affects firms' technology innovation and various performances through three paths: promotion [6-8], inhibition [9-11], and uncertainty [12-15]. Similarly, EREG has three kinds of effects on firm performance: promotion [5], restraint [3,16,17], and uncertainty [18,19]. Accordingly, three perspectives have emerged from prior results, i.e., Traditional Hypothesis, Porter Hypothesis, and Uncertainty Hypothesis [20]. With increasing literature on EREG, there is also a growing debate on its actual effect, especially the effect mechanism of EREG on firms' sustainable development.

Another important discussion on the validity of Porter Hypothesis is that the roles of some key factors in firms have not been identified, e.g., firms' capability and innovation modes [21]. It has been suggested that the mechanism and specific effect of EREG in firms through different types of innovations need to be investigated in micro perspectives [2,3]. Additionally, some studies indicated that firms' environmental commitment (ECOM) can effectively transform the external pressure into their innovation behaviors [22]. As such, it needs to examine whether different types of innovation modes and ECOM can become specific premises to establish the Porter Hypothesis and whether EREG's effect on firm performance can be identified.

This paper aims to analyze the link between EREG and firm sustainable development under the multiple mediating effects of sustainability exploration innovation (SEXPLOR), sustainability exploitation innovation (SEXPLOI), and ECOM through using two dimensions of sustainable development (business performance and environmental performance). To cater for our research goals, this paper will contribute to the literature on EREG and sustainable innovation in the following ways. First, we attempt to expand the traditional Porter Hypothesis targeting the aspect of firm's sustainable development based on two types of sustainable innovation as well as their corresponding internal variables with the mediating role of firms' ECOM, SEXPLOR, and SEXPLOI. Second, this paper also designs the multiple mediating roles of ECOM and SEXPLOR as well as ECOM and SEXPLOI in the relationship between EREG and sustainable development to enrich the understanding on how the external regulation tools evolves into the issues in terms of firms' final sustainability.

The rest of this paper is organized as follows. We review the literature and propose research hypotheses (Section 2). Then, we describe the research method, including the questionnaire design, data collection, and variable measurement (Section 3). After that, we present empirical results and thus verify our hypotheses (Section 4). Finally, we conclude this paper and further discuss key findings (Section 5).

\section{Literature Review and Research Hypotheses}

\subsection{Environmental Regulation}

EREG was defined as a series of guiding, normative, and binding environmental policies that are implemented by governments to prevent and control the environmental pollution produced from firms [11]. EREG requires firms to increase their investment in environmental management and improve technology innovation related to environmental protection [23,24]. As one of the effective ways for governments to manage firms' environmental behaviors, EREG plays a key role in limiting the harmful effects of economic activity on the natural environment [22,25]. At the same time, EREG that is flexible and properly designed is more likely to help firms establish low-cost and other differentiated competitive edges $[2,4,5]$. Thus, proper EREG is a crucial driver for private firms to improve firms' environmental performance (FEPER) and business performance (FBPER) [6,21]. However, some studies also suggested that EREG requires firms to adopt practices that may increase environmental management costs and inevitably crowd out the capital investment in R\&D. In this case, EREG can restrain firm's sustainable development by inhibiting firm's technology innovation and business performance $[3,16,17]$. 
Many studies aimed to address the debate on the link between EREG, firm innovation, and performance. Most have sought to provide theoretical explanations and empirical evidence for a "weak" or "strong" Porter Hypothesis based on the research frameworks composed of EREG, firm innovation, and performance. However, few studies addressed the important problem noted by Porter and Van Der Linde (1995) [24] —namely, how to formulate appropriate EREG and create an effective effect path that results in win-win scenarios. Prior studies also neglected the role of internal factors for firms, e.g., operations capability, managerial attitude, and strategic position in the relationship between EREG and firm performance $[14,21]$. It is necessary, therefore, to integrate governmental and private firms' behaviors and systematically investigate whether and how EREG will affect sustainable innovation and firm performance through these firms' internal factors.

\subsection{Environmental Commitment}

ECOM refers to efforts made by firms in terms of environmental management and protection [17,26]. A high level of ECOM indicates that firms usually have a strong willingness to adopt sustainable practices to balance firm development and environmental protection [1,27]. Prior studies found that ECOM prompted firms to take initiative in participating in the environmental management, and thus integrate it into firms' strategies to improve firm's environmental performance through proactive environmental management $[28,29]$. Prior studies presented the positive effects of ECOM on business performance, innovation capability, and competitive edges [30-32]. Therefore, ECOM will play a key effect in improving both environmental and business performance through promoting the implementation of sustainable practices.

In terms of exploring why firms implement ECOM, prior studies found that ECOM is usually proposed or constructed by firms under external pressures, e.g., government regulation [33,34], cultural climate [35], or shareholders' pressure [22,36]. Some studies found that top managers' willingness and strategic orientation can also promote the implementation of ECOM as well $[35,37]$.

Prior studies also identified the antecedents and consequences of ECOM. They found that external environmental policy can effectively enhance ECOM and firms with ECOM are more willing to implement innovation practices related to environmental management [31,38,39]. However, few studies integrated both external antecedents (e.g., EREG) and internal consequences (e.g., innovation and business performance) of ECOM into the research framework. It is necessary, therefore, to investigate whether ECOM plays a key effect in the Porter hypothesis and how ECOM can meditate the relationship among EREG, firm innovation, and firm performance.

\subsection{Sustainability Exploration Innovation and Sustainability Exploitation Innovation}

To address the conflict between firm development and environmental protection, Maletič et al. (2014) proposed the theoretical frameworks of SEXPLOR and SEXPLOI based on the prior "exploration-exploitation" paradigm and sustainable development theory [40]. SEXPLOR focuses on reducing both environmental costs and material consumption over the life of product through enhancing exploratory innovation, aiming to achieve firms' sustainability and obtain future prosperity in competitive edges [40]. SEXPLOI, meanwhile, emphasizes the reduction of the use of materials, water, and energy with continuously improving production efficiency through enhancing exploitation innovation; this aims to contribute to existing competitive edges in the short-term [39].

SEXPLOR and SEXPLOI both focus on how to achieve the economic growth and environmental protection with helping firms to cope with ecological, social, and economic challenges [41]. However, the effect of SEXPLOR and SEXPLOI on firm performance differs according to key factors, e.g., the country, the level of market competitiveness, and EREG [42,43]. For instance, Maletič et al. (2015) found that sustainable practices related to SEXPLOR or SEXPLOI can improve business performance by increasing innovation performance [43]. Maletič et al. (2016) provided evidence that the effect of SEXPLOR and SEXPLOI on firm performance depends on different contextual and motivational conditions, e.g., institutional environments [44]. In general, SEXPLOR and SEXPLOI may lead to 
a higher performance for firms with environmentally friendly technologies, favorable work-life balance among employees, and long-term relationships with quality suppliers.

To broaden the understanding of SEXPLOR and SEXPLOI, Maletič et al. (2018) adopted the contingency theory to examine the relationship between SEXPLOR/SEXPLOI and firm performance. They found that the effect of SEXPLOR and SEXPLOI on firm performance depend on various contexts, including environmental competitiveness and uncertainty [45]. Subsequent studies expanded the factors that affect the relationship between SEXPLOR/ SEXPLOI, and firm performance. For instance, Xing et al. (2019) found that the relationship among SEXPLOR, SEXPLOI, and firm performance depends on the level of EREG [42].

It appears that there is disagreement on not only the implementation of SEXPLOR and SEXPLOI, but also their effects on firm performance. As two types of innovation practices, SEXPLOR and SEXPLOI play the key effects in promoting firms' sustainable development [46]. Therefore, the effect of SEXPLOR and SEXPLOI on firms' sustainable development should be investigated in a more depth with considering the different contexts that firms face.

\subsection{Direct Effects of EREG}

As an effective tool for environmental management, EREG plays a key effect in achieving goals of environmental protection through normalizing firms' behaviors [18,47]. EREG sets a series of environmental protection standards for industries and firms, e.g., energy consumption standards, pollutant emission standards, and utilization rates for recyclable materials [48]. These standards require firms to reduce energy consumption and pollutants or to avoid pollutants emissions through the innovation in products and processes. These sustainable practices will help firms to meet or exceed EREG standards, which increasingly drive FEPER [21]. At the same time, EREG can keep firms that do not meet environmental standards from entering the market, or it can close down existing firms that fail to meet such standards [49]. Therefore, EREG increasingly drives FEPER through enhancing their sustainable practices and optimizing the industrial structure.

EREG can improve business performance through enhancing the environmental innovation efficiency and optimizing market structures. First, EREG will motivate firms to carry out more types of technology innovation, e.g., product/process innovation, thus reducing energy consumption, pollutants emissions, and operating costs $[10,50]$. Therefore, the low-cost and proactive management mode brought about by technology innovation can help firms to gain more competitive edges [18]. At the same time, EREG can lead to the effective operation of eco-innovation [3]. Environmentally friendly products produced by eco-innovation can lend firms a competitive edge and thus improve firm's business performance [51]. Finally, EREG can keep firms that do not meet emission standards from entering the market through raising the entry criteria, e.g., raising pollutants emission standards, energy use standards, and energy efficiency standards [49,52]. In this way, EREG can optimize the market structure, reduce intensive competition, and increase firms' market share, thus contributing to the improvement of firm performance. Based on above analysis, we propose following hypotheses:

H1a. EREG is positively associated with FEPER.

H1b. EREG is positively associated with FBPER.

\subsection{The Mediating Effects of SEXPLOR and SEXPLOI}

\subsubsection{The Effects of EREG on SEXPLOR and SEXPLOI}

From the perspective of compliance cost compensation, EREG requires firms to increase their investment in environmental innovation to improve environmental quality, which is likely to increase environmental management costs $[15,53]$. From the viewpoint of innovation compensation, however, cost-saving innovation can outweigh compliance costs through pollution prevention and energy conservation, among other aspects [54,55]. With respect to whether adopting the cost compensation or 
innovation compensation perspective, some studies provided the evidence that EREG significantly promotes environmental innovation.

SEXPLOR and SEXPLOI emphasize using exploration and exploitation innovation, respectively, to achieve sustainable development [39]. These two types of innovation have the dual purpose of technology innovation and environmental protection [42]. From the perspective of innovation, SEXPLOR and SEXPLOI are two types of conventional technology innovation, but from the perspective of environmental protection, they both aim to achieve firms' sustainable development. Therefore, in terms of the innovation compensation effect, EREG is likely to promote technology innovation, e.g., SEXPLOR and SEXPLOI. In terms of cost compensation, EREG is likely to promote environmental innovation, e.g., SEXPLOR and SEXPLOI as well.

\subsubsection{The Effects of SEXPLOR and SEXPLOI on FEPER and FBPER}

Prior studies investigated the effect of SEXPLOR and SEXPLOI on FEPER and FBPER $[40,42,43]$. Maletič et al. (2014) suggested that SEXPLOR aims to create new and environmentally friendly products, technologies, and knowledge through exploration innovation [39]. SEXPLOR is likely to enhance firms' capability to obtain sustainable solutions, e.g., green products, process, and knowledge. In terms of technology innovation, new designs, products, and distribution channels brought about by SEXPLOR can help to find new markets and differentiate firms from their competitors $[42,45,56]$. Thus, firms with a high-level SEXPLOR are likely to obtain long-term competitive edges and the higher business performance. From the perspective of sustainable development, SEXPLOR emphasizes such development and attempts to reduce environmental impacts during the product cycle through product and process innovation. Environmentally friendly products, technologies, and knowledge help to reduce material consumption and increase recycling rates [57]. Therefore, SEXPLOR may lead to high levels of green development and ecological protection, and then improve FEPER.

SEXPLOI refers to a continuous improvement of existing products/designs through exploitation innovation, which aims to reduce the use of materials, water, and energy, to enhance the existing competitive edges [44]. Firms with high levels of SEXPLOI are better able to strengthen and improve existing knowledge and technologies and improve product/service quality, which can enhance their capability to meet market demands [39]. From the perspective of technology innovation, SEXPLOI focuses on improving existing knowledge and technology, improving existing designs, expanding the application of existing products and services, and increasing the efficiency of existing distribution channels to consolidate existing markets and consumers. Further, SEXPLOI can ensure the viability of an organization against its competitors through providing lower-price and higher-quality products [58-60]. Thus, SEXPLOI is likely to improve business performance through the nature of exploitation innovation. In terms of sustainable development, SEXPLOI is committed to green development, ecological protection, and reducing environmental impacts through process improvements during the product cycle [45]. Therefore, SEXPLOI enhances firms' capability and thus improves pollution prevention and recycling utilization to reduce the consumption of resources and energy. In this case, firms can reduce overall environmental costs and improve environmental performance [44].

Based on above analysis, we propose following hypotheses:

H2a. SEXPLOR positively mediates the relationship between EREG and FEPER.

H2b. SEXPLOI positively mediates the relationship between EREG and FEPER.

H2c. SEXPLOR positively mediates the relationship between EREG and FBPER.

H2d. SEXPLOI positively mediates the relationship between EREG and FBPER. 


\subsection{The Mediating Effect of ECOM}

\subsubsection{The Effect of EREG on ECOM}

Prior studies suggested that external pressure plays a determining effect in driving firms to make ECOM [22], where EREG is a main driving force [34,61]. EREG compels firms to consider environmental issues in daily management activities while establishing corresponding standards for firms' environmental management [18]. This external pressure caused by EREG forces firms to strike a balance between enhancing market competitiveness and meeting ecological responsibility.

To meet EREG requirements, firms must increase their investment in both product and process innovation to effectively control pollution, which can increase costs $[15,35]$. Firms must overcome such cost rise to remain competitiveness in the markets [6]. The pressure to protect the environment and maintain competitiveness is likely to increase firms' willingness and motivation to implement environmental management [62]. Some studies suggested that under a strict EREG, firms voluntarily participate in environmental protection and strive to cut resource use and waste generation through proactive environmental management and technology innovation $[18,63]$.

\subsubsection{The Effect of ECOM on Firm Performance}

ECOM can improve corporate environmental performance and business performance in terms of two aspects. First, prior studies found that ECOM is an effective internal motivation that plays a determining role in promoting firms' engagement in environmental protection and enhancing their competitiveness [22,64]. Firms with a higher level of ECOM are willing to implement the pollution prevention and control, green product design, efficiency improvement, and waste recycling as well as utilization. These proactive behaviors caused by ECOM can reduce firms' impact on environment [28,29,32]. Additionally, ECOM plays a key effect in encouraging employees' productivity through the improved corporate culture and employees' "pride" [1]. Therefore, ECOM significantly improves the effectiveness and efficiency of environmental management and protection. Second, firms with a higher level of ECOM may strengthen their contact with customers and thus strive to provide a better understanding of environmental needs. Based on information about the market demand, firms can enhance or reinforce their positive images in the marketplace as "good corporate citizens" through creating environmentally friendly products that meet markets' needs [65]. Therefore, we propose that ECOM can effectively improve firms' competitiveness.

Based on above analysis, we propose following hypotheses:

H3a. ECOM positively mediates the relationship between EREG and FEPER.

H3b. ECOM positively mediates the relationship between EREG and FBPER.

\subsection{The Mediating Effect of SEXPLOR, SEXPLOI, and ECOM}

Firms with the higher level of ECOM usually have a positive attitude toward reducing negative impacts on the environment [66]. ECOM can promote the implementation of proactive and voluntary actions, e.g., reducing costs and increasing efficiency, cutting resource use and waste generation, and creating environmentally friendly products, which aim to improve firms' environmental management capability $[35,67,68]$. Kim et al. (2015) found that ECOM drives firms to seek new knowledge as well as skills to implement environmental practices [69]. Prior research also suggested that ECOM should result in greater efforts to protect the environment or to achieve good sustainable development [37]. The higher the level of ECOM, the stronger the willingness of firms to carry out innovation activities related to reducing environmental pollution. As two types of sustainability innovation, SEXPLOR and SEXPLOI can effectively mitigate or eliminate the negative effects of firm development on the environment through conducting exploration innovation and exploitation innovation [63,70]. Therefore, we suggest that firms with higher level of ECOM prefer to invest more resources in SEXPLOR and SEXPLOI to achieve environmental protection and sustainable development. 
Integrating hypotheses $\mathrm{H} 2 \mathrm{a}, \mathrm{H} 2 \mathrm{~b}$, and $\mathrm{H} 3 \mathrm{a}$, this paper proposes that EREG can positively affect SEXPLOR and SEXPLOI through ECOM and then improve FEPER. Based on the assumptions in H2c, $\mathrm{H} 2 \mathrm{~d}$, and H3b, we suggest that EREG can positively affect SEXPLOR and SEXPLOI through ECOM and then improve FBPER. Accordingly, we propose following hypotheses:

H4a. ECOM and SEXPLOR positively mediate the relationship between EREG and FEPER.

H4b. ECOM and SEXPLOI positively mediate the relationship between EREG and FEPER.

H4c. ECOM and SEXPLOR positively mediate the relationship between EREG and FBPER.

H4d. ECOM and SEXPLOI positively mediate the relationship between EREG and FBPER.

Based on above hypotheses, Figure 1 presents a model representing the theoretical relationships among EREG, ECOM, SEXPLOR, SEXPLOI, and two types of firm performance.

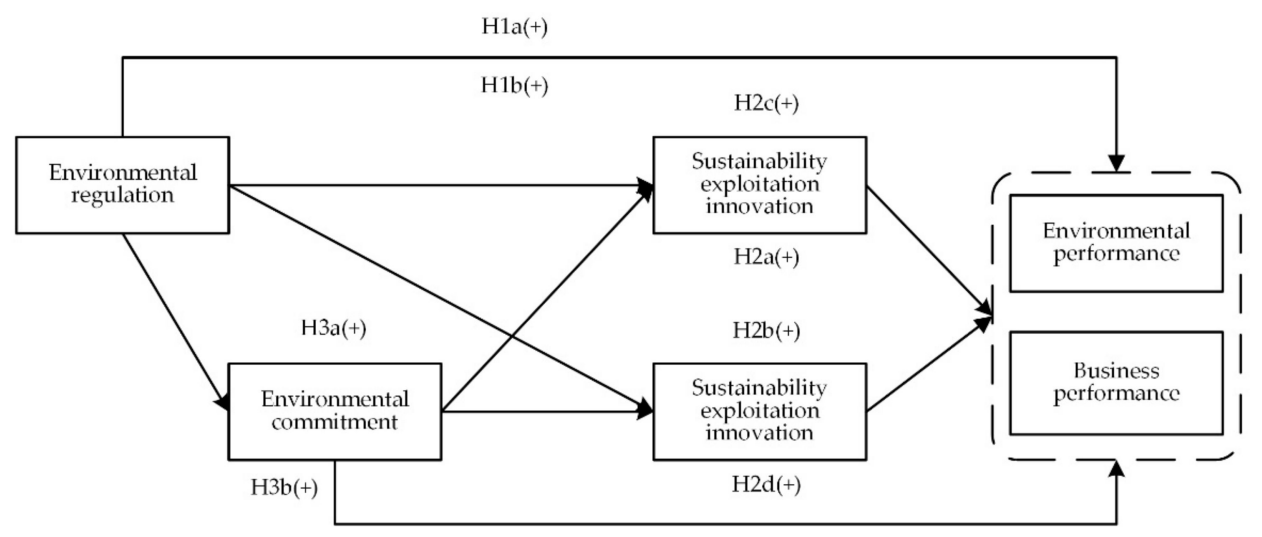

Figure 1. The conceptual framework

\section{Materials and Method}

\subsection{Samples and Data Collection}

To test the relationships among our designed variables, we use the empirical data obtained from Chinese manufacturing firms through the questionnaire survey. The surveyed areas covered China's eastern, central, western, and northeastern regions based on the China Statistical Yearbook. We sent out and collected questionnaires from March 2018 to May 2018. To ensure the representativeness, we randomly selected 926 firms to contact by phone or e-mail before the formal survey. As suggested by prior studies [71], CEOs, senior managers, and directors of R\&D departments responsible for firms' sustainability innovation were selected as respondents. A total of 877 questionnaires were sent out in paper form or by e-mail, with 585 returned, for a response rate of $66.70 \%$. After the processing and screening, 205 invalid questionnaires were removed; among these, 16 were incomplete, 107 had obvious filling-out problems, and 82 were not filled out by CEOs, senior managers, or directors of R\&D departments. Finally, 380 valid questionnaires were obtained, for a $64.96 \%$ effective rate.

The proportions of 380 valid questionnaires returned by organizations located in the eastern, central, western, and northeastern regions were $45.00 \%, 24.47 \%, 12.11 \%$, and $18.42 \%$, respectively. In terms of organizational size, the firms included micro firms (less than 20 employees; 6.05\%), small-sized firms (20-299 employees; 27.89\%), middle-sized firms (300-999 employees; 35.79\%), and large-sized firms (more than 1000 employees; $30.26 \%$ ). In terms of age, $7.37 \%$ of the firms had existed 1-5 years, $20.53 \%$ 6-10 years, $15.26 \% 11-15$ years, $20.26 \% 16-20$ years, and $36.58 \%$ more than 20 years. The ownership types included collectively owned $(29.47 \%)$, privately held $(22.11 \%)$, state held $(28.68 \%)$, state owned $(5.79 \%)$, and foreign owned (13.95\%).

Questionnaires were collected from the same source in the same way; common method variance (CMV) may influence both item validity and reliability [72,73]. If common method variance exists, 
confirmatory factor analysis (CFA) containing all constructs should produce a single-method factor [74]. To check for the potential effect of CMV, we conducted CFA through using Mplus 7.0. The results presented that the goodness-of-fit indices $(\chi 2 / \mathrm{df}=6.188, \mathrm{CFI}=0.633, \mathrm{TLI}=0.608, \mathrm{RMSEA}=0.117)$ indicated a poor fit for the single-factor model. Harman's one-factor test was also conducted through using SPSS 20.0 via the principal components. The results of the nonrotating factor analysis presented that the first principal component accounted for $36.37 \%$ of the total variance (less than $40 \%$ ). Thus, CMV did not lead to method bias in this paper.

\subsection{Variable Measures}

The questionnaire consisted of six construct measurements: firms' environmental performance (FEPER), firms' business performance (FBPER), environmental regulation (EREG), environmental commitment (ECOM), sustainability exploration innovation (SEXPLOR), and sustainability exploitation innovation (SEXPLOI). Questionnaire items were measured through the 7-point Likert scale ranging from "strongly disagree" (1) to "strongly agree" (7).

\subsubsection{Dependent Variables}

Firms' environmental performance (FEPER). According to Wagner and Schaltegger (2004) and Maletič et al. (2018), FEPER is usually used to assess the reduction of environmental effects through reducing energy and materials, reducing emissions, and increasing efficiency [45,75]. We measure FEPER through the four items improved by Maletič et al. (2016) [40].

Firms' business performance (FBPER). FBPER refers to a firm's degree of business success [40,71]. Following prior studies [71,76], we measure FBPER through four items: rate of investment (ROI), sales, profit, and market share. Through a 7 -point Likert scale (1=very rarely, $7=$ very commonly), respondents were asked to assess whether their firm's business performance is successful in terms of ROI, sales, profit, and market share compared to their major competitors.

\subsubsection{Independent Variables}

Environmental regulation (EREG). EREG refers to government environmental policies intended to reduce firms' environmental impacts and encourage them to pursue environmental innovation [11,77]. Following Eiadat et al. (2008) [11], we measure EREG through four items. Respondents were asked to indicate the extent to which environmental laws affecting their firms (1) contain stringent standards, (2) are appropriate for China's contexts, (3) are very clear, and (4) are effective for tackling environmental problems.

\subsubsection{Mediating Variables}

Environmental commitment (ECOM). ECOM refers to firms' past and current efforts regarding environmental management and protection [17]. ECOM was measured based on six items adopted from prior studies [78] (see Appendix A).

Sustainability innovation (SEXPLOR and SEXPLOI). As two types of sustainability innovation, SEXPLOR and SEXPLOI reflect the implementation of a firm's sustainability-related innovation [39]. According to prior research [44,45], SEXPLOR was divided into sustainable product and process development (SPPD) and sustainability-oriented learning (SOL). SPPD refers to the green process engineering and product innovation, and SOL refers to developing the capabilities and competence for sustainability-related innovation [39,42]. Following Maletič et al. (2016) and Xing et al. (2019) [42,44], SPPD, SOL, and SEI were measured through four items, four items, and six items, respectively, improved by Maletič et al. (2014) and Maletič et al. (2015) [39,43] (see Appendix A). 


\subsubsection{Control Variables}

Many studies found that firm size and age significantly affect their environmental management behaviors [79]. To ensure this paper's model was robust, we use two firm-level variables as control variables (firm size and age). Following Demirel et al. (2018) [79], we measure firm size through using the total number of employees and firm age using the number of years since the firm was established.

\subsection{Instrument Reliability and Validation}

According to prior studies [42,44], SEXPLOR is a single second-order construct consisting of two sub constructs: SPPD and SOL. We examine the reliability of SPPD and SOL through SPSS 22.0. Table 1 shows that SPPD and SOL have Cronbach's $\alpha$ values of 0.852 and 0.850 , respectively, which are higher than the recommended level of 0.7. The factor loadings of all items are between 0.757 and 0.856 , which are above the recommended levels. Finally, results present that the first-order latent variables, SPPD and SOL, have a good reliability.

Table 1. Second-order construct of sustainability exploration innovation (SEXPLOR).

\begin{tabular}{ccccc}
\hline \multirow{2}{*}{ Variable } & \multirow{2}{*}{ First-Order Construct } & \multicolumn{2}{c}{ First-Order Construct } & \multirow{2}{*}{ Cronbach's $\alpha$} \\
\cline { 3 - 4 } & & Item & Factor Loading & \\
& & SPPD1 & 0.856 & \\
& Sustainable product and & SPPD2 & 0.809 & 0.852 \\
& process development (SPPD) & SPPD3 & 0.759 & \\
Sustainability exploration & & SPPD4 & 0.825 & 0.850 \\
innovation (SEXPLOR) & & SOL1 & 0.831 & \\
& Sustainability-oriented & SOL2 & 0.826 & 0.757 \\
\hline
\end{tabular}

After the reliability test for the second-order construct SEXPLOR, we examine the reliability of data from 380 questionnaires using SPSS 22.0. Table 2 presents that the Cronbach's $\alpha$ coefficients of all measuring scales range from 0.842 to $0.898(>0.7)$. The KMO values for all measure scales are all higher than the recommended cut-off value of 0.6 , and Bartlett's test $F$ values are all statistically significant $(p<0.001)$. Finally, the results in Table 2 indicate that all measure scales are stable and have a high reliability.

Table 2. Measurement reliability.

\begin{tabular}{cccc}
\hline Variable & Cronbach's $\boldsymbol{\alpha}$ & KMO Value & Bartlett's Test F Value \\
\hline EREG & 0.854 & 0.812 & 0.000 \\
SEXPLOI & 0.871 & 0.895 & 0.000 \\
SEXPLOR & 0.854 & 0.866 & 0.000 \\
ECOM & 0.898 & 0.893 & 0.000 \\
FBPER & 0.863 & 0.827 & 0.000 \\
FEPER & 0.842 & 0.815 & 0.000 \\
\hline
\end{tabular}

To analyze the validity of items, confirmatory factor analysis (CFA) was conducted using Mplus 7.0. The results indicate that the questionnaire data have a high goodness of fit with the designed model $(\chi 2 / \mathrm{df}=1.337, \mathrm{CFI}=0.962, \mathrm{TLI}=0.958, \mathrm{RMSEA}=0.038)$. In Table 3, the factor loadings of measuring scales range from 0.712 to $0.872(>0.7)$. Further, the composite reliabilities (CR) of all measurement constructs range from 0.706 to $0.903(>0.6)$. To evaluate the convergent validity of scales, we estimate the average variance extracted (AVE) per Fornell and Larcker (1981) [80]. As presented in Table 3, the AVE of all constructs ranges from 0.545 to 0.654 (>0.5). The results indicate that the convergent validity of all measurement constructs in this paper is acceptable. 
Table 3. Reliability values and factor loadings for the scale items $(\mathrm{N}=380)$.

\begin{tabular}{|c|c|c|c|c|}
\hline Variable & Measurement Item & Factor Loading & $\mathrm{CR}$ & AVE \\
\hline \multirow{4}{*}{ EREG } & EREG1 & 0.776 & \multirow{4}{*}{0.858} & \multirow{4}{*}{0.602} \\
\hline & EREG2 & 0.796 & & \\
\hline & EREG3 & 0.751 & & \\
\hline & EREG4 & 0.779 & & \\
\hline \multirow{6}{*}{ SEXPLOI } & SEXPLOI1 & 0.734 & \multirow{6}{*}{0.879} & \multirow{6}{*}{0.547} \\
\hline & SEXPLOI2 & 0.752 & & \\
\hline & SEXPLOI3 & 0.730 & & \\
\hline & SEXPLOI4 & 0.743 & & \\
\hline & SEXPLOI5 & 0.751 & & \\
\hline & SEXPLOI6 & 0.726 & & \\
\hline \multirow[b]{2}{*}{ SEXPLOR } & SPPD & 0.712 & \multirow[b]{2}{*}{0.706} & \multirow{2}{*}{0.545} \\
\hline & SOL & 0.764 & & \\
\hline \multirow{6}{*}{ ECOM } & ECOM1 & 0.829 & \multirow{6}{*}{0.903} & \multirow{6}{*}{0.609} \\
\hline & ECOM2 & 0.775 & & \\
\hline & ECOM3 & 0.794 & & \\
\hline & ECOM4 & 0.750 & & \\
\hline & ECOM5 & 0.748 & & \\
\hline & ECOM6 & 0.784 & & \\
\hline \multirow{4}{*}{ FBPER } & FBPER1 & 0.872 & \multirow{4}{*}{0.883} & \multirow{4}{*}{0.654} \\
\hline & FBPER2 & 0.805 & & \\
\hline & FBPER3 & 0.794 & & \\
\hline & FBPER4 & 0.760 & & \\
\hline \multirow{4}{*}{ FEPER } & FEPER1 & 0.749 & \multirow{4}{*}{0.851} & \multirow{4}{*}{0.588} \\
\hline & FEPER2 & 0.787 & & \\
\hline & FEPER3 & 0.749 & & \\
\hline & FEPER4 & 0.781 & & \\
\hline
\end{tabular}

Note: All item loadings are significant at $p<0.01$.

Additionally, we examine the discriminant validity through comparing the square roots of AVE of a variable with the correlation coefficient between the variable and the rest of it. As presented in Table 4, the square root of AVE of each variable is higher than the correlation coefficient between the variable and the rest of the latent variables. The results confirm that the discriminant validity of all variables is acceptable. Table 4 presents the mean, standard deviation (SD), square root of AVE, and correlations between variables.

Table 4. Descriptive statistics and discriminant validity.

\begin{tabular}{lccccccccc}
\hline Variable & Mean & SD & $\mathbf{1}$ & $\mathbf{2}$ & $\mathbf{3}$ & $\mathbf{4}$ & $\mathbf{5}$ & $\mathbf{6}$ & $\mathbf{7}$ \\
\hline 1. Age & 1.187 & 0.312 & & & & & & \\
2. Size & 2.654 & 0.732 & $0.508^{* *}$ & & & & & \\
3. EREG & 5.612 & 0.732 & $0.129 *$ & 0.029 & $\mathbf{0 . 7 7 6}$ & & & \\
4. SEXPLOI & 5.325 & 0.932 & 0.040 & 0.072 & $0.420^{* *}$ & $\mathbf{0 . 7 4 0}$ & & \\
5. SEXPLOR & 5.427 & 0.899 & -0.006 & 0.071 & $0.414^{* *}$ & $0.640^{* *}$ & $\mathbf{0 . 7 3 8}$ & & \\
6. ECOM & 5.015 & 0.837 & $0.173^{* *}$ & $0.146^{* *}$ & $0.527^{* *}$ & $0.527^{* *}$ & $0.515^{* *}$ & $\mathbf{0 . 7 8 0}$ & \\
7. FBPER & 4.926 & 1.155 & 0.049 & 0.044 & $0.274^{* *}$ & $0.310^{* *}$ & $0.358^{* *}$ & $0.369^{* *}$ & $\mathbf{0 . 8 0 9}$ \\
8. FEPER & 5.355 & 0.882 & 0.048 & 0.023 & $0.337^{* *}$ & $0.581^{* *}$ & $0.583^{* *}$ & $0.587^{* *}$ & $0.516^{* *}$ \\
\hline
\end{tabular}

Note: Two-tailed tests significant at ${ }^{*} p<0.05,{ }^{* *} p<0.01$. Diagonal values in bold represent the square root of AVE.

\section{Results}

\subsection{Direct and Indirect Effects of EREG on FEPER}

Following prior studies [81-83], bootstrapping (1000 resamples) was used to test the structural equation model (SEM) consisting of EREG, ECOM, SEXPLOR, SEXPLOI, FEPER, and FBPER. As Hayes (2013) suggested [84], we analyze 1000 bootstrap resamples and select the $99 \%$ bias-corrected confidence interval to assess statistical significance and path coefficients using Mplus 7.0. The SEM results 
$(\chi 2 / \mathrm{df}=1.90, \mathrm{RMSEA}=0.049, \mathrm{TLI}=0.931, \mathrm{CFI}=0.924)$ presented that the full model has good fit. Figure 2, Tables 5 and 6 jointly present the full-model results. Table 5 presents that the $99 \%$ bias-corrected confidence interval for EREG (lower $=-0.541$, upper $=0.140$ ) includes 0 , which indicates that EREG does not have a significant direct effect on FEPER ( $\beta=-0.097, p>0.05)$. Hence, H1a is not supported.

To test the mediating effect of SEXPLOR, SEXPLOI, and ECOM, we separately examine whether the $99 \%$ bias-corrected confidence interval included 0. First, in the test for $\mathrm{H} 2 \mathrm{a}$, the $99 \%$ bias-corrected confidence interval for the instantaneous indirect effect of EREG on FEPER via SEXPLOR includes 0 (lower $=-0.209$, upper $=0.453$ ). Thus, $\mathrm{H} 2 \mathrm{a}$ is not supported. Second, in the test for $\mathrm{H} 2 \mathrm{~b}$, the $99 \%$ bias-corrected confidence interval includes 0 (lower $=-0.029$, upper $=0.164$ ); hence, H2b is also not supported. Third, in the test for $\mathrm{H3a}$, the $99 \%$ bias-corrected confidence interval includes zero (lower $=-0.185$, upper $=0.477$ ); thus, H3a is not supported.

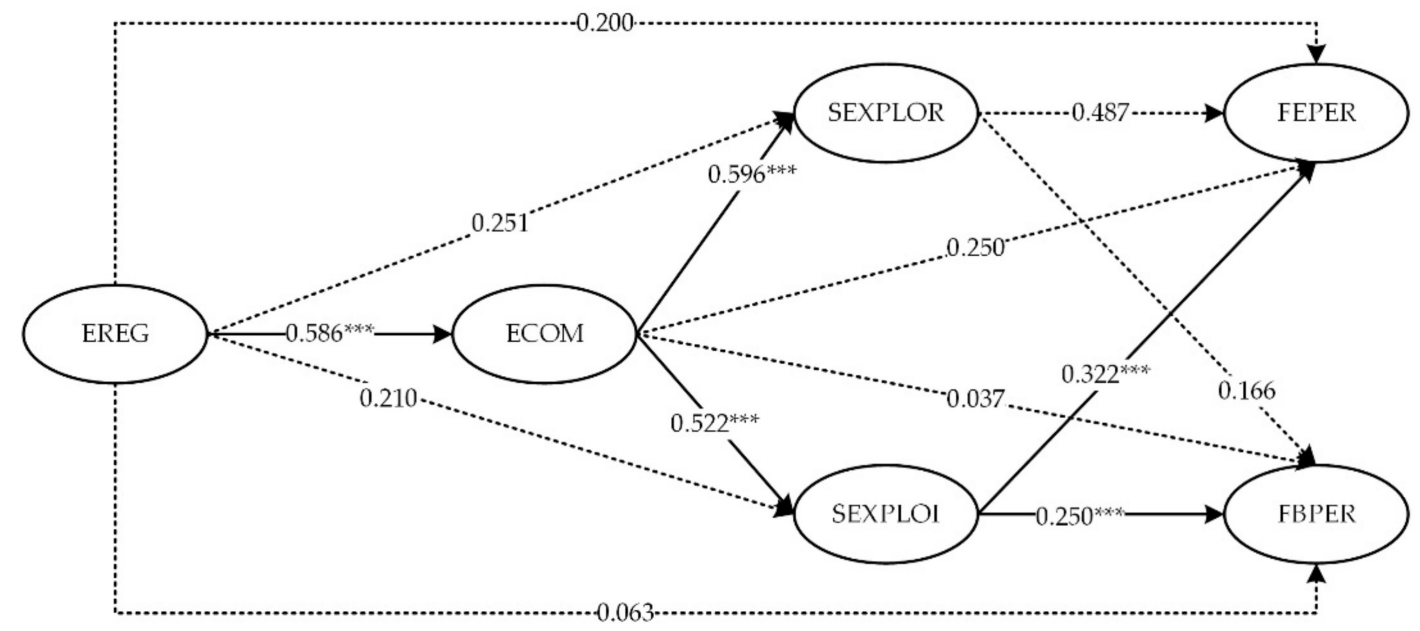

Figure 2. Multiple mediation model results. Note: ${ }^{* * *} p<0.01$. A dotted line means not significant at the $99 \%$ level.

Table 5. Results for the effects of environmental regulation (EREG) on firms' environmental performance (FEPER) $(\mathrm{N}=380)$.

\begin{tabular}{|c|c|c|c|c|c|}
\hline \multirow{2}{*}{ Corresponding Hypothesis } & \multirow{2}{*}{ Effect } & \multicolumn{3}{|c|}{ Bootstrapping Percentile $99 \%$ CI } & \multirow{2}{*}{ Result } \\
\hline & & Boot Effect & Lower $0.5 \%$ & Upper $0.5 \%$ & \\
\hline & Direct effect & & & & \\
\hline $\mathrm{H} 1 \mathrm{a}$ & $\begin{array}{c}\text { FEPER } \\
\text { EREG }\end{array}$ & -0.200 & -0.541 & 0.140 & Not supported \\
\hline & $\begin{array}{c}\text { Indirect effect } \\
\text { FEPER }\end{array}$ & & & & \\
\hline $\mathrm{H} 2 \mathrm{a}$ & $\begin{array}{l}\text { SEXPLOR } \\
\text { EREG } \\
\text { FEPER }\end{array}$ & 0.122 & -0.209 & 0.453 & Not supported \\
\hline $\mathrm{H} 2 \mathrm{~b}$ & $\begin{array}{l}\text { SEXPLOI } \\
\text { EREG } \\
\text { FEPER }\end{array}$ & 0.067 & -0.029 & 0.164 & Not Supported \\
\hline $\mathrm{H} 3 \mathrm{a}$ & $\begin{array}{c}\text { ECOM } \\
\text { EREG } \\
\text { FEPER }\end{array}$ & 0.154 & -0.185 & 0.477 & Not Supported \\
\hline $\mathrm{H} 4 \mathrm{a}$ & $\begin{array}{l}\text { SEXPLOR } \\
\text { ECOM } \\
\text { EREG }\end{array}$ & 0.170 & -0.166 & 0.506 & Not Supported \\
\hline $\mathrm{H} 4 \mathrm{~b}$ & $\begin{array}{c}\text { FEPER } \\
\text { SEXPLOI } \\
\text { ECOM } \\
\text { EREG }\end{array}$ & 0.098 & 0.017 & 0.179 & Supported \\
\hline
\end{tabular}


Table 6. Results for the effects of EREG on firms' business performance (FBPER) $(\mathrm{N}=380)$.

\begin{tabular}{|c|c|c|c|c|c|}
\hline \multirow{2}{*}{ Corresponding Hypothesis } & \multirow{2}{*}{ Effect } & \multicolumn{3}{|c|}{ Bootstrapping Percentile $99 \%$ CI } & \multirow{2}{*}{ Result } \\
\hline & & Boot Effect & Lower $0.5 \%$ & Upper $0.5 \%$ & \\
\hline & Direct effect & & & & \\
\hline $\mathrm{H} 1 \mathrm{~b}$ & $\begin{array}{l}\text { FBPER } \\
\text { EREG }\end{array}$ & 0.063 & -0.099 & 0.225 & Not supported \\
\hline & $\begin{array}{c}\text { Indirect effect } \\
\text { FBPER }\end{array}$ & & & & \\
\hline $\mathrm{H} 2 \mathrm{c}$ & $\begin{array}{c}\text { SEXPLOR } \\
\text { EREG } \\
\text { FBPER }\end{array}$ & 0.047 & -0.043 & 0.127 & Not supported \\
\hline $\mathrm{H} 2 \mathrm{~d}$ & $\begin{array}{l}\text { SEXPLOI } \\
\text { EREG } \\
\text { FBPER }\end{array}$ & 0.047 & -0.022 & 0.127 & Not supported \\
\hline $\mathrm{H} 3 \mathrm{~b}$ & $\begin{array}{l}\text { ECOM } \\
\text { EREG } \\
\text { FBPER }\end{array}$ & 0.022 & -0.096 & 0.140 & Not supported \\
\hline $\mathrm{H} 4 \mathrm{c}$ & $\begin{array}{c}\text { SEXPLOR } \\
\text { ECOM } \\
\text { EREG }\end{array}$ & 0.058 & -0.022 & 0.138 & Not Supported \\
\hline $\mathrm{H} 4 \mathrm{~d}$ & $\begin{array}{c}\text { FBPER } \\
\text { SEXPLOI } \\
\text { ECOM } \\
\text { EREG }\end{array}$ & 0.077 & 0.005 & 0.149 & Supported \\
\hline
\end{tabular}

Further, we examine the multiple mediation effect of ECOM with developing SEXPLOR and SEXPLOI. The $99 \%$ bias-corrected confidence interval for the indirect effect of EREG on FEPER via ECOM and SEXPLOR includes 0 (lower $=-0.166$, upper $=0.506$ ), which indicates that both ECOM and SEXPLOR do not sequentially mediate the relationship between EREG and FEPER. Thus, H4a is not supported. Additionally, the $99 \%$ bias-corrected confidence interval for the indirect effect of EREG on FEPER via ECOM and SEXPLOI does not include 0 (lower $=0.017$, upper $=0.179$, which verifies that ECOM and SEXPLOI sequentially mediate the relationship between EREG and FEPER ( $\beta=0.0790$, $p<0.01)$. Thus, H4b is supported.

\subsection{Direct and Indirect Effects of EREG on FBPER}

To reveal the relationships among EREG, SEXPLOR, SEXPLOI, ECOM, and FBPER, we test the direct and indirect effects of EREG on FBPER. Table 6 presents the multiple mediation model results. The $99 \%$ bias-corrected confidence interval for EREG (lower $=-0.099$, upper $=0.225$ ) includes 0 , which indicates that the path coefficient between EREG and FBPER is not significant. Thus, H1b is not supported.

To verify $\mathrm{H} 2 \mathrm{c}, \mathrm{H} 2 \mathrm{~d}$, and $\mathrm{H} 3 \mathrm{a}$, we analyze the $99 \%$ bias-corrected confidence intervals for three paths coefficients (Table 6). The 99\% bias-corrected confidence intervals for SEXPLOR (lower $=-0.043$, upper $=0.127)$, SEXPLOI (lower $=-0.022$, upper $=0.127)$, and ECOM $($ lower $=-0.096$, upper $=0.140)$ includes 0 . This indicates that the path coefficients between EREG and ECOM via SEXPLOR ( $\beta=0.047$, $p>0.01)$, between EREG and ECOM via SEXPLOI $(\beta=0.047, p>0.05)$, and between EREG and ECOM via $\mathrm{ECOM}(\beta=0.027, p>0.01)$ were not significant. Thus, $\mathrm{H} 2 \mathrm{c}, \mathrm{H} 2 \mathrm{~d}$, and $\mathrm{H} 3 \mathrm{~b}$ are not supported.

Further, we examine the two multiple mediating paths composed of ECOM with SEXPLOR, ECOM, and SEXPLOI. As presented in Table 6, the 99\% bias-corrected confidence interval for the indirect effect of EREG on FBPER via ECOM and SEXPLOR includes 0 (lower $=-0.022$, upper $=0.138$ ). This indicates that the path coefficient between EREG and FBPER via ECOM and SEXPLOR is not significant $(\beta=0.064, p>0.05)$. Hence, H4c is not supported, i.e., ECOM and SEXPLOR do not sequentially mediate the relationship between EREG and FBPER. Additionally, the $99 \%$ bias-corrected confidence interval for the indirect effect of EREG on FBPER via ECOM and SEXPLOI does not include 0 (lower $=0.077$, upper $=0.149$ ), which confirms that both ECOM and SEXPLOI sequentially mediate 
the relationship between EREG and FBPER. The path coefficient is significant $(\beta=0.0790, p<0.01)$. Hence, H4d is supported.

\section{Discussion and Conclusions}

Prior studies investigated the key effect of environmental regulation in promoting firms to organize green innovation, and thus improve environmental management as well as sustainable development $[4,6,15,51]$. However, there are still disagreements in terms of the link between environmental regulation, innovation, and performance that corresponds the gap of Porter Hypothesis $[6,8,85]$. Overall, few papers investigated how to establish an effective path by which environmental regulation promote sustainable development by exploring the mediating effect of internal factors for firms. Therefore, this paper provides a new insight into the effect of environmental regulation on sustainable development through the multiple mediating effect of environmental commitment and two types of sustainable innovations: sustainability exploration innovation and sustainability exploitation innovation. The key conclusions are as follows:

(1) The direct and positive effect of environmental regulation on firm sustainable development that covers environmental performance and business performance is not significant. This finding agrees with Testa (2011) and Rexhäuser and Rammer (2014) [6,12], but differs from López-Gamero et al. (2010) and Mi et al. (2018) that found that environmental regulation can improve firm performance $[3,18]$. This inconsistency can be due to the different effect mechanisms of environmental regulation on firm performance. In the short-term, environmental regulation may decrease firm performance through increasing their environmental management costs. In the long-term, however, environmental regulation can increase firm performance through improving the efficiency of environmental innovation [13]. This difference between short-term and long-term perspectives triggers the effect of environmental regulation on firm performance to be not significant with another reason that there is still a lack of broad environmental regulation practices in China compared to developed countries [86].

(2) The mediating role of environmental commitment in correlation between environmental regulation and firm sustainable development is not significant. These results do not support the empirical analysis of Carrillo-Higueras et al. (2018) with a potential reason that as an internal motivation, environmental commitment can effectively enhance firms' willingness on the environmental protection [1]. As prior suggestions, environmental commitment can improve firm performance through effective paths composed of a series of key organizational factors, e.g., environmental management capabilities, environmental activities, and environmental management systems $[36,69,87]$.

(3) Environmental commitment and sustainability exploitation innovation sequentially mediate the relationship between environmental regulation and sustainable development. These results also indicate that environmental commitment and sustainability exploitation innovation sequentially mediate the relationship between environmental regulation and business performance, which agrees with Ramanathan et al. (2010) and Xie et al. (2019) that concluded that environmental regulation plays a key role in improving environmental quality and firm performance $[4,5]$. However, the effect paths of environmental regulation on performance are entirely different. Following prior studies $[6,20,21,79]$, we emphasize to explore the effect of organizational factors on the link among environmental regulation, innovation mode, and firm performance. To achieve this goal, we not only examine the direct effect of environmental regulation on firms' innovation performance, but also the effect of key organizational factors in the links among environmental regulation, firm innovation, and firm performance [18,21,54].

\subsection{Theoretical Implications}

This paper makes several contributions to the existing literature on the Porter hypothesis and sustainable innovation. First, few studies noted the effect of certain organizational factors in connecting environmental regulation and firm innovation. As suggested by prior studies [21,35,54], some organizational factors are important for affecting the relationship among environmental regulation, environmental performance, and business performance. It is in response to the recommendations that 
the effects of different types of innovation should be noted when examining the Porter hypothesis [71]. This paper highlights two important conditions of the Porter hypothesis: environmental commitment and sustainability exploitation innovation.

Second, this paper contributes to the Porter hypothesis literature through framing a conceptual model that links environmental regulation, environmental commitment, sustainability exploration innovation, sustainability exploitation innovation, environmental performance, and business performance. In this way, it provides a holistic view for explaining the multiple mediating effects of environmental commitment and sustainability exploitation innovation. These findings offer a framework for exploring the links between environmental regulation and organizational factors and the effect of this link on the relationship between environmental regulation and firm's sustainable development.

Third, this paper further divides environmental innovation into sustainability exploration innovation and sustainability exploitation innovation, and identifies the effects of two different types of sustainable innovation in the correlation between environmental regulation and firm performance. The mediating role of two types of innovations in the link among environmental regulation, environmental commitment, and firm performance suggests that environmental commitment and sustainability exploitation innovation are fundamental for realizing positive effects of environmental regulation on firm performance. This paper thus provides deeper insight into the effect of ambidextrous sustainability innovation in the "strong" Porter hypothesis.

\subsection{Practical Implications}

Our findings also offer some suggestions for policy-makers and managers. First, prior studies suggested that governments should design proper environmental regulation, e.g., command-and-control regulations, market-based regulations, and informal regulations, to compel firms to enhance their environmental innovation. Our findings indicate that the effect of environmental regulation on firm performance depends on the level of environmental commitment in firms. A lack of environmental commitment leads to ineffective environmental regulation. Therefore, we suggest that policy-makers need to identify whether firms have high levels of environmental commitment before designing environmental regulations.

Second, prior studies found that the different relationships between environmental regulation and firm performance depend on different types of regulations, innovation capability, strategic position, and altruistic motivation $[6,20,21,79]$. This paper found that sustainability exploitation innovation can significantly mediate the relationship among environmental regulation environmental commitment, and environmental performance (or business performance). Sustainability exploitation innovation that directly helps firms improve efficiency, reduce costs, and improve performance, can comply with higher production costs and reduce the competitiveness of products caused by environmental regulation. It suggests that to manage environmental pressure, managers should be aware of the different types of sustainability innovation. It is necessary, then, to allocate more resources to sustainability exploitation innovation when firms need to enhance environmental protection and obtain competitive edges in the short-term.

\subsection{Limitations and Further Research}

This paper has some limitations. First, we distinguish two types of environmental innovation from the ambidextrous sustainability innovation perspective and examine the mediating effects of sustainability exploration innovation and sustainability sexploitation innovation. Other types of innovation, e.g., eco-innovation, open innovation, and green innovation, should be incorporated into future research frameworks related to the Porter hypothesis.

Second, this paper only incorporates environmental commitment into the conceptual framework and examine its meditating effect. However, other internal factors, e.g., stakeholder pressure, strategic position, and customer demand, also enhance proactive environmental protection and environmental innovation. Moreover, there are few quantitative studies on the complex interconnections between 
environmental regulation and key internal factors. Future studies should quantitatively examine the effects of internal key factors on the relationships among environmental regulation, sustainable innovation, and business performance.

Third, prior studies indicated that the effect of environmental regulation on innovation and performance depends on the type of environmental regulation $[6,18,54]$. This paper does not consider the effect of different types of environmental regulations on different technology innovations, and the reasons why there are three kinds of relationships between environmental regulation and technology innovation were not discovered as well. Therefore, future studies should strengthen this point that is beneficial constructing the "strong" Porter Hypothesis.

Author Contributions: Conceptualization, J.W. and X.X.; Methodology, X.X. and L.S.; software, X.X.; Investigation, X.X. and T.L.; Data curation, X.X. and L.S.; Writing—original draft preparation, X.X. and T.L.; Writing一review and editing, J.W., T.L. and Y.Z.; Supervision, J.W.

Funding: The authors appreciate the support form the Key Projects of the National Natural Science Foundation of China (Project No. 71673115; 71801113); the Fundamental Research Funds for the Central Universities (Project No. JUSRP11760; JGLX19_108), the Fundamental Research Funds for Jiangsu Philosophy and social Science (Project No. 2017SJB0815), and Fundamental Research Funds for the Central Universities (Project No. 3072019CFJ0903), Jiangsu Social Science Foundation (Project No. 19GLC004).

Conflicts of Interest: There is no any interest conflict among authors.

\section{Appendix A}

Table A1. Measuring items.

\begin{tabular}{|c|c|}
\hline Variables & Description \\
\hline \multicolumn{2}{|c|}{ Environmental performance } \\
\hline FEPER1 & $\begin{array}{l}\text { The efficiency of the consumption of raw materials has improved during last } \\
3 \text { years. }\end{array}$ \\
\hline FEPER 2 & $\begin{array}{l}\text { The resource consumption (thermal energy, electricity, water) has decreased, e.g., } \\
\text { per unit of income and per unit of production, during last } 3 \text { years. }\end{array}$ \\
\hline FEPER 3 & The percentage of recycled materials has increased during last 3 years \\
\hline FEPER 4 & $\begin{array}{l}\text { The waste ratio, e.g., } \mathrm{kg} \text { per unit of product and } \mathrm{kg} \text { per employee per year, has } \\
\text { decreased during last } 3 \text { years. }\end{array}$ \\
\hline Business performance & $\begin{array}{l}\text { Relative to main competitors, our firm's performance is very successful in the last } \\
3 \text { years in terms of }\end{array}$ \\
\hline FBPER1 & Return on investment (ROI) \\
\hline FBPER2 & Growth of sales \\
\hline FBPER3 & Profit \\
\hline FBPER4 & Market share in main products and markets. \\
\hline \multicolumn{2}{|c|}{$\begin{array}{l}\text { Sustainability exploration } \\
\text { innovation-SPPD }\end{array}$} \\
\hline SPPD1 & $\begin{array}{l}\text { Our firm makes improvements to radically reduce environmental impacts of } \\
\text { products and services' lifecycles. }\end{array}$ \\
\hline SPPD2 & $\begin{array}{l}\text { Our firm adjusts existing products and services to reduce negative environmental } \\
\text { and social impact. }\end{array}$ \\
\hline SPPD3 & $\begin{array}{l}\text { Our firm's undertakes regularly business process reengineering with a focus on } \\
\text { green perspectives. }\end{array}$ \\
\hline SPPD4 & $\begin{array}{l}\text { Our firm acquires innovative environmentally friendly technologies and } \\
\text { processes. }\end{array}$ \\
\hline \multicolumn{2}{|c|}{$\begin{array}{l}\text { Sustainability exploration } \\
\text { innovation-SOL }\end{array}$} \\
\hline SOL1 & $\begin{array}{l}\text { Our firm continuously strengthens employees' knowledge and skills to improve } \\
\text { efficiency of current sustainability practices. }\end{array}$ \\
\hline SOL2 & $\begin{array}{l}\text { Our firm is characterized by a learning culture stimulating innovation for } \\
\text { sustainability. }\end{array}$ \\
\hline SOL3 & $\begin{array}{l}\text { Our firm upgrades employees' current knowledge and skills based on examples } \\
\text { of best practices in corporate social responsibility. }\end{array}$ \\
\hline SOL4 & $\begin{array}{l}\text { Our firm searches for external sources, e.g., partners, customers, and research } \\
\text { institutions, of knowledge in our search for innovative ideas related to } \\
\text { sustainability. }\end{array}$ \\
\hline
\end{tabular}


Table A1. Cont.

\begin{tabular}{|c|c|}
\hline Variables & Description \\
\hline \multicolumn{2}{|c|}{$\begin{array}{l}\text { Sustainability exploitation } \\
\text { innovation }\end{array}$} \\
\hline SEXPLOI1 & Our firm responds to existing stakeholder issues in a regular/systematic way. \\
\hline SEXPLOI 2 & $\begin{array}{l}\text { Our firm constantly evaluates its external environment to uncover issues of } \\
\text { importance to key stakeholders, including customers, suppliers, and local } \\
\text { communities. }\end{array}$ \\
\hline SEXPLOI 3 & $\begin{array}{l}\text { Our firm's business processes are flexible allowing us to achieve high levels of } \\
\text { responsiveness towards key stakeholder needs and demands. }\end{array}$ \\
\hline SEXPLOI 4 & $\begin{array}{l}\text { Our firm involves key market stakeholders (customers, suppliers) early in the } \\
\text { product/service design and development stage. }\end{array}$ \\
\hline SEXPLOI 5 & $\begin{array}{l}\text { Our firm makes use of appropriate tools and techniques to reduce the variability } \\
\text { of key processes. }\end{array}$ \\
\hline SEXPLOI 6 & $\begin{array}{l}\text { Our firm has established key performance indicators (KPIs) to determine if the } \\
\text { organization is meeting sustainability goals. }\end{array}$ \\
\hline \multicolumn{2}{|c|}{ Environmental commitment } \\
\hline ECOM 1 & Our firm has a perfect environmental plan. \\
\hline ECOM 2 & Our firm has an insightful environmental vision or mission. \\
\hline ECOM 3 & Our firm has communicated its environmental plans to its employees. \\
\hline ECOM 4 & $\begin{array}{l}\text { Our firm has communicated its environmental vision or mission to its } \\
\text { stakeholders. }\end{array}$ \\
\hline ECOM 5 & Our firm has a well-developed environment, health, and safety unit. \\
\hline ECOM 6 & $\begin{array}{l}\text { Our firm's budget planning includes the concerns of environmental investment or } \\
\text { procurement. }\end{array}$ \\
\hline \multicolumn{2}{|c|}{$\begin{array}{l}\text { Each respondent was asked to indicate the extent }(1=\text { strongly disagree to } 7=\text { strongly agree }) \text { to which environmental } \\
\text { laws that impact our firm }\end{array}$} \\
\hline EREG 1 & contain stringent standards; \\
\hline EREG 2 & are appropriate for China's contexts; \\
\hline EREG 3 & are very clear; \\
\hline EREG 4 & are effective in tackling environmental problems directly. \\
\hline
\end{tabular}

\section{References}

1. Carrillo-Higueras, F.; Prajogo, D.; Smith, L. Environmental commitment and its drivers in the Australian wine industry: A behavioural approach. Australas. J. Environ. Manag. 2018, 25, 439-458. [CrossRef]

2. Zhou, G.; Liu, W.; Zhang, L.; She, K. Can environmental regulation flexibility explain the Porter Hypothesis?-An empirical study based on the data of China's listed enterprises. Sustainability 2019, 11, 2214. [CrossRef]

3. Mi, Z.; Zeng, G.; Xin, X.; Shang, Y.; Hai, J. The extension of the Porter hypothesis: Can the role of environmental regulation on economic development be affected by other dimensional regulations? J. Clean. Prod. 2018, 203, 933-942.

4. Ramanathan, R.; Black, A.; Nath, P.; Muyldermans, L. Impact of environmental regulations on innovation and performance in the UK industrial sector. Manag. Decis. 2010, 10, 1493-1513. [CrossRef]

5. Xie, J.; Nozawa, W.; Yagi, M.; Fujii, H.; Managi, S. Do environmental, social, and governance activities improve corporate financial performance? Bus. Strategy Environ. 2019, 28, 286-300. [CrossRef]

6. Testa, F.; Iraldo, F.; Frey, M. The effect of environmental regulation on firms' competitive performance: The case of the building \& construction sector in some EU regions. J. Environ. Manag. 2011, 92, 2136-2144.

7. Lanoie, P.; Laurent-Lucchetti, J.; Johnstone, N.; Ambec, S. Environmental policy, innovation and performance: New insights on the porter hypothesis. J. Econ. Manag. Strategy 2011, 20, 803-842. [CrossRef]

8. Jiang, Z.; Wang, Z.; Li, Z. The effect of mandatory environmental regulation on innovation performance: Evidence from China. J. Clean. Prod. 2018, 203, 482-491. [CrossRef]

9. Feng, C.; Wang, M.; Liu, G.C.; Huang, J.B. Green development performance and its influencing factors: A global perspective. J. Clean. Prod. 2017, 144, 323-333. [CrossRef]

10. Zhao, X.; Sun, B. The influence of Chinese environmental regulation on corporation innovation and competitiveness. J. Clean. Prod. 2016, 112, 1528-1536. [CrossRef]

11. Eiadat, Y.; Kelly, A.; Roche, F.; Eyadat, H. Green and competitive? An empirical test of the mediating role of environmental innovation strategy. J. World Bus. 2008, 43, 131-145. [CrossRef] 
12. Rexhäuser, S.; Rammer, C. Environmental innovations and firm profitability: Unmasking the Porter hypothesis. Environ. Resour. Econ. 2014, 57, 145-167. [CrossRef]

13. Peuckert, J. What shapes the impact of environmental regulation on competitiveness? Evidence from executive opinion surveys. Environ. Innov. Soc. Transit. 2014, 10, 77-94. [CrossRef]

14. Triguero, A.; Moreno-Mondéjar, L.; Davia, M.A. Eco-innovation by small and medium-sized firms in Europe: From end-of-pipe to cleaner technologies. Innovation 2015, 17, 24-40. [CrossRef]

15. Guo, Y.; Xia, X.; Zhang, S.; Zhang, D. Environmental regulation, government R\&D funding and green technology innovation: Evidence from China provincial data. Sustainability 2018, 10, 940-960.

16. Triebswetter, U.; Wackerbauer, J. Integrated environmental product innovation in the region of Munich and its impact on company competitiveness. J. Clean. Prod. 2008, 16, 1484-1493. [CrossRef]

17. Gao, J.; Bansal, P. Instrumental and integrative logics in business sustainability. J. Bus. Ethics 2013, 112, 241-255. [CrossRef]

18. López-Gamero, M.D.; Molina-Azorín, J.F.; Claver-Cortés, E. The potential of environmental regulation to change managerial perception, environmental management, competitiveness and financial performance. J. Clean. Prod. 2010, 18, 963-974. [CrossRef]

19. Wang, M.X.; Zhao, H.H.; Cui, J.X.; Fan, D.; Lv, B.; Wang, G.; Li, Z.H.; Zhou, G.J. Evaluating green development level of nine cities within the Pearl River Delta, China. J. Clean. Prod. 2018, 174, 315-323. [CrossRef]

20. Peng, B.; Tu, Y.; Wei, G. Can environmental regulations promote corporate environmental responsibility? Evidence from the moderated mediating effect model and an empirical study in China. Sustainability 2018, 10, 641. [CrossRef]

21. Ramanathan, R.; He, Q.; Black, A.; Ghobadian, A.; Gallear, D. Environmental regulations, innovation and firm performance: A revisit of the Porter hypothesis. J. Clean. Prod. 2017, 155, 79-92. [CrossRef]

22. Jahanshahi, A.A.; Brem, A. Antecedents of corporate environmental commitments: The role of customers. Int. J. Environ. Res. Public Health 2018, 15, 1191. [CrossRef] [PubMed]

23. Ambec, S.; Barla, P. Can environmental regulations be good for business? An assessment of the Porter hypothesis. Energy Stud. Rev. 2006, 14, 42-62. [CrossRef]

24. Porter, M.E.; Van Der Linde, C. Toward a new conception of the environment-competitiveness relationship. J. Econ. Perspect. 1995, 9, 97-118. [CrossRef]

25. Gray, W.B.; Shadbegian, R.J. Plant vintage, technology, and environmental regulation. J. Environ. Econ. Manag. 2003, 46, 384-402. [CrossRef]

26. Mcallister, I.; Studlar, D.T. Green versus Brown: Explaining environmental commitment in Australia. Soc. Sci. Q. 1999, 80, 775-792. [PubMed]

27. Aragón-Correa, J.A.; Sharma, S.A. Contingent resource-based view of proactive corporate environmental Strategy. Acad. Manag. Rev. 2003, 28, 71-88. [CrossRef]

28. Hirunyawipada, T.; Xiong, G. Corporate environmental commitment and financial performance: Moderating effects of marketing and operations capabilities. J. Bus. Res. 2018, 86, 22-31. [CrossRef]

29. Tung, A.; Baird, K.; Schoch, H. The association between the adoption of an environmental management system with organisational environmental performance. Australas. J. Environ. Manag. 2014, 21, 281-296. [CrossRef]

30. Suasana, I.G.A.K.; Ni, W.E. Environmental commitment and green innovation reaching success new products of creative industry in Bali. J. Bus. Retail Manag. Res. 2018, 12, 246-250. [CrossRef]

31. Cordón Lagares, E.; García Ordaz, F.; del Hoyo, J.J.G. Innovation, environmental commitment, internationalization and sustainability: A survival analysis of Spanish marine aquaculture firms. Ocean Coast. Manag. 2018, 151, 61-68. [CrossRef]

32. Chang, C.H. The influence of corporate environmental ethics on competitive advantage: The mediation role of green innovation. J. Bus. Ethics 2011, 104, 361-370. [CrossRef]

33. Berry, M.A.; Rondinelli, D.A. Proactive corporate management: A new industrial revolution. Acad. Manag. Exec. 1993, 12, 38-50. [CrossRef]

34. Roy, M.J.; Boiral, O.; Lagacé, D. Environmental commitment and manufacturing excellence: A comparative study within Canadian industry. Bus. Strategy Environ. 2001, 10, 257-268. [CrossRef]

35. Lynes, J.K.; Dredge, D. Going green: Motivations for environmental commitment in the airline industry. A case study of Scandinavian Airlines. J. Sustain. Tour. 2010, 14, 116-138. [CrossRef] 
36. Henriques, I.; Sadorsky, P. The relationship between environmental commitment and managerial perceptions of stakeholder importance. Acad. Manag. J. 1999, 42, 87-99.

37. Liu, Z.; Li, J.; Zhu, H.; Cai, Z.; Wang, L. Chinese firms' sustainable development-The role of future orientation, environmental commitment, and employee training. Asia Pac. J. Manag. 2014, 31, 195-213. [CrossRef]

38. Su, S.; Tung, A.; Baird, K. The influence of environmental commitment on the take-up of environmental management initiatives. Australas. J. Environ. Manag. 2017, 24, 289-301. [CrossRef]

39. Maletič, M.; Maletič, D.; Dahlgaard, J.J.; Dahlgaard-Park, S.M.; Gomišček, B. Sustainability exploration and sustainability exploitation: From a literature review towards a conceptual framework. J. Clean. Prod. 2014, 79, 182-194. [CrossRef]

40. Maletič, M.; Maletič, D.; Dahlgaard, J.J.; Dahlgaard-Park, S.M.; Gomišček, B. Effect of sustainability-oriented innovation practices on the overall organisational performance: An empirical examination. Total Qual. Manag. Bus. Excell. 2016, 27, 1171-1190. [CrossRef]

41. Schaltegger, S.; Beckmann, M.; Hansen, E.G. Transdisciplinarity in corporate sustainability: Mapping the field. Bus. Strategy Environ. 2013, 22, 219-229. [CrossRef]

42. Xing, X.; Wang, J.; Tou, L. The relationship between green organization identity and corporate environmental performance: The mediating role of sustainability exploration and exploitation innovation. Int. J. Environ. Res. Public Health 2019, 16, 921. [CrossRef] [PubMed]

43. Maletič, M.; Maletič, D.; Dahlgaard, J.J.; Dahlgaard-Park, S.M.; Gomišcek, B. Do corporate sustainability practices enhance organizational economic performance? Int. J. Qual. Serv. Sci. 2015, 7, 184-200. [CrossRef]

44. Maletič, M.; Maletič, D.; Gomišček, B. The impact of sustainability exploration and sustainability exploitation practices on the organisational performance: A cross-country comparison. J. Clean. Prod. 2016, 138, 158-169. [CrossRef]

45. Maletič, M.; Maletič, D.; Gomišček, B. The role of contingency factors on the relationship between sustainability practices and organizational performance. J. Clean. Prod. 2018, 171, 423-433. [CrossRef]

46. Martinez-Conesa, I.; Soto-Acosta, P.; Palacios-Manzano, M. Corporate social responsibility and its effect on innovation and firm performance: An empirical research in SMEs. J. Clean. Prod. 2017, 142, 2374-2383. [CrossRef]

47. Filbeck, G.; Gorman, R.F. The relationship between the environmental and financial performance of public utilities. Environ. Resour. Econ. 2004, 29, 137-157. [CrossRef]

48. Watson, M.; Emery, A.R.T. Environmental management and auditing systems: The reality of environmental self-regulation. Manag. Audit. J. 2004, 19, 916-928. [CrossRef]

49. Majumdar, S.K.; Marcus, A.A. Rules versus discretion: The productivity consequences of flexible regulation. Acad. Manag. J. 2001, 44, 170-179.

50. Hart, S.L. A natural-resource-based view of the firm. Acad. Manag. Rev. 1995, 20, 986-1014. [CrossRef]

51. You, D.; Zhang, Y.; Yuan, B. Environmental regulation and firm eco-innovation: Evidence of moderating effects of fiscal decentralization and political competition from listed Chinese industrial companies. J. Clean. Prod. 2019, 207, 1072-1083. [CrossRef]

52. Feng, Z.; Zeng, B.; Ming, Q. Environmental regulation, two-way foreign direct investment, and green innovation efficiency in China's manufacturing industry. Int. J. Environ. Res. Public Health 2018, 15, 2292. [CrossRef] [PubMed]

53. Feichtinger, G.; Hartl, R.F.; Kort, P.M.; Veliov, V.M. Environmental policy, the porter hypothesis and the composition of capital: Effects of learning and technological progress. J. Environ. Econ. Manag. 2005, 50, 434-446. [CrossRef]

54. Li, R.; Ramanathan, R. Exploring the relationships between different types of environmental regulations and environmental performance: Evidence from China. J. Clean. Prod. 2018, 196, 1329-1340. [CrossRef]

55. Rubashkina, Y.; Galeotti, M.; Verdolini, E. Environmental regulation and competitiveness: Empirical evidence on the Porter hypothesis from European manufacturing sectors. Energy Policy 2015, 83, 288-300. [CrossRef]

56. Jansen, J.J.P.; Van den Bosch, F.A.J.; Volberda, H.W. Exploratory innovation, exploitative innovation, and ambidexterity: The impact of environmental and organizational antecedents. Schmalenbach Bus. Rev. 2005, 57, 351-363. [CrossRef]

57. Tomšič, N.; Bojnec, Š.; Simčič, B. Corporate sustainability and economic performance in small and medium sized enterprises. J. Clean. Prod. 2015, 108, 603-612. [CrossRef] 
58. Sirén, C.A.; Kohtamäki, M.; Kuckertz, A. Exploration and exploitation strategies, profit performance, and the mediating role of strategic learning: Escaping the exploitation trap. Strateg. Entrep. J. 2012, 6, 18-41. [CrossRef]

59. Auh, S.; Menguc, B. Balancing exploration and exploitation: The moderating role of competitive intensity. J. Bus. Res. 2005, 58, 1652-1661. [CrossRef]

60. Prajogo, D.I. The strategic fit between innovation strategies and business environment in delivering business performance. Int. J. Prod. Econ. 2016, 171, 241-249. [CrossRef]

61. Berry, M.A.; Rondinelli, D.A. Proactive corporate environmental management: A new industrial revolution. Acad. Manag. Perspect. 1998, 12, 38-50. [CrossRef]

62. Managi, S.; Opaluch, J.J.; Jin, D.; Grigalunas, T.A. Environmental regulations and technological change in the offshore oil and gas industry. Land Econ. 2005, 81, 303-319. [CrossRef]

63. Khanna, M.; Anton, W.R.Q. What is driving corporate environmentalism: Opportunity or threat? Corp. Environ. Strategy 2002, 9, 409-417. [CrossRef]

64. Delmas, M.; Toffel, M.W. Stakeholders and environmental management practices: An institutional framework. Bus. Strategy Environ. 2004, 13, 209-222. [CrossRef]

65. Chang, C.H.; Chen, Y.S. Green organizational identity and green innovation. Manag. Decis. 2013, 51, 1056-1070. [CrossRef]

66. Collins, E.; Lawrence, S.; Pavlovich, K.; Ryan, C. Business networks and the uptake of sustainability practices: The case of New Zealand. J. Clean. Prod. 2007, 15, 729-740. [CrossRef]

67. Parker, C.M.; Redmond, J.; Simpson, M. Intervention strategies to engage small and medium enterprises in environmental protection. Environ. Plan. C Gov. Policy 2009, 27, 22.

68. Aragón-Correa, J.A.; Hurtado-Torres, N.; Sharma, S.; García-Morales, V.J. Environmental strategy and performance in small firms: A resource-based perspective. J. Environ. Manag. 2008, 86, 88-103. [CrossRef]

69. Kim, H.J.; Park, J.; Wen, J. General managers' environmental commitment and environmental involvement of lodging companies. Int. J. Contemp. Hosp. Manag. 2015, 27, 1499-1519. [CrossRef]

70. Maletič, M.; Maletič, D.; Dahlgaard, J.J.; Dahlgaard-Park, S.M.; Gomišček, B. The relationship between sustainability-oriented innovation practices and organizational performance: Empirical evidence from Slovenian organizations. Organizacija 2014, 47, 3-13. [CrossRef]

71. Cheng, C.C.J.; Yang, C.L.; Sheu, C. The link between eco-innovation and business performance: A Taiwanese industry context. J. Clean. Prod. 2014, 64, 81-90. [CrossRef]

72. Podsakoff, P.M.; MacKenzie, S.B.; Lee, J.-Y.; Podsakoff, N.P. Common method biases in behavioral research: A critical review of the literature and recommended remedies. J. Appl. Psychol. 2003, 88, 879-903. [CrossRef] [PubMed]

73. MacKenzie, S.B.; Podsakoff, P.M. Common method bias in marketing: Causes, mechanisms, and procedural remedies. J. Retail. 2012, 88, 542-555. [CrossRef]

74. Podsakoff, P.M.; Organ, D.W. Self-reports in organizational research: Problems and prospects. J. Manag. 1986, 12, 531-544. [CrossRef]

75. Wagner, M.; Schaltegger, S. The effect of corporate environmental strategy choice and environmental performance on competitiveness and economic performance: An empirical study of EU manufacturing. Eur. Manag. J. 2004, 22, 557-572. [CrossRef]

76. Im, S.; Workman, J.P. Market orientation, creaeivity, and new product performance in high-technology firms. J. Mark. 2004, 68, 114-132. [CrossRef]

77. Cao, W.; Wang, H.; Ying, H. The effect of environmental regulation on employment in resource-based areas of China-An empirical research based on the mediating effect model. Int. J. Environ. Res. Public Health 2017, 14, 1598. [CrossRef]

78. Nath, P.; Ramanathan, R. Environmental management practices, environmental technology portfolio, and environmental commitment: A content analytic approach for UK manufacturing firms. Int. J. Prod. Econ. 2016, 171, 427-437. [CrossRef]

79. Demirel, P.; Iatridis, K.; Kesidou, E. The impact of regulatory complexity upon self-regulation: Evidence from the adoption and certification of environmental management systems. J. Environ. Manag. 2018, 207, 80-91. [CrossRef]

80. Fornell, C.; Larcker, D.F. Evaluating structural equation models with unobservable variables and measurement error. J. Mark. Res. 1981, 18, 39-50. [CrossRef] 
81. Hayes, A.F.; Preacher, K.J. Quantifying and testing indirect effects in simple mediation models when the constituent paths are nonlinear. Multivar. Behav. Res. 2010, 45, 627-660. [CrossRef] [PubMed]

82. Loock, C.M.; Staake, T.; Thiesse, F. Motivating energy-efficient behavior with green IS: An investigation of goal setting and the role of defaults. MIS Q. 2013, 37, 1313-1332. [CrossRef]

83. Cepeda-Carrion, I.; Leal-Millán, A.G.; Martelo-Landroguez, S.; Leal-Rodriguez, A.L. Absorptive capacity and value in the banking industry: A multiple mediation model. J. Bus. Res. 2016, 69, 1644-1650. [CrossRef]

84. Hayes, A.F. Introduction to mediation, moderation, and conditional process analysis: A regression-based approach. J. Educ. Meas. 2013, 51, 335-337.

85. Xie, R.; Yuan, Y.; Huang, J. Different types of environmental regulations and heterogeneous influence on "green" productivity: Evidence from China. Ecol. Econ. 2017, 132, 104-112. [CrossRef]

86. Wang, X.; Sun, C.; Wang, S.; Zhang, Z.; Zou, W. Going green or going away? A spatial empirical examination of the relationship between environmental regulations, biased technological progress, and green total factor productivity. Int. J. Environ. Res. Public Health 2018, 15, 1917. [CrossRef]

87. Laguir, I.; Marais, M.; El Baz, J.; Stekelorum, R. Reversing the business rationale for environmental commitment in banking: Does financial performance lead to higher environmental performance? Manag. Decis. 2018, 56, 358-375. [CrossRef]

(C) 2019 by the authors. Licensee MDPI, Basel, Switzerland. This article is an open access article distributed under the terms and conditions of the Creative Commons Attribution (CC BY) license (http://creativecommons.org/licenses/by/4.0/). 